\title{
Science Education and Science Writing in Hindi in the North West Provinces (1860-1900)
}

\author{
Pooja Mishra* \\ (Received 20 June 2016; revised 14 October 2017)
}

\begin{abstract}
The vernacularisation of science passes through various processes that are dependent upon historical and cultural context. Science writing and popularization in various vernacular languages of the Indian subcontinent such as Urdu, Bengali, Tamil, Marathi, Malayalam commenced in the first half of the nineteenth century itself. Science writing in Hindi began rather late when compared to the other vernacular. The present paper engages with science education and its linkages with science popularization in Hindi, exploring the socio-political context for the late arrival of science writing in Hindi. The paper investigates the connectedness of the education system, the emergence of Hindi as a language, and the role of the print media in the popularization of science in Hindi.
\end{abstract}

Key words: Hindi science writing, Print readership, Science education, Social history, Vernacular science education

\section{InTRODUCTION}

The nineteenth century is marked as a period of far-reaching socio-economic and political change in colonial India. Changes in the socio-political and economic structure of the subcontinent were accompanied by various social conflicts manifested in peasant, tribal, and anticaste movements towards the latter half of the nineteenth century (Sarkar, 1983; Chandra, et.al. 1989; Desai, 2000). The movement for acquiring a linguistic identity for Hindi was the result of a controversy during the nineteenth century generated around the issue of replacing the Persian script and language by Nāgarī as the official language of North-Western Provinces (henceforth NWP) and Oudh. This movement for a Hindi linguistic identity subsequently acquired religious overtones (Rai, 1998; Orisini, 2002; King, 1994). The Hindi language movement emerged after the 1880 s but its seeds were sown towards the beginning of the century, following the establishment of Fort William College in 1800. The conflict began to germinate during the 1840 s on the ground prepared by the colonial government through its educational policies.

The paper seeks to explore the late arrival of science writings in Hindi. Studies show that popularisation of science and science writing in the vernaculars of the Indian subcontinent such as Bengali, Urdu, Tamil, Assamese etc commenced in the early nineteenth century (Sehgal, Sangwan, Mahanti, 2000; Raina, and S Habib, 2004; Prakash, 1999). However, Hindi was a latecomer, though small efforts commenced in the 1870s but accelerated after the 1890s and substantially after 1900 (Mishra, 2001). The focus of the paper is on science writing in Hindi. At the turn of century the genre of science writing was clearly linked to the agenda of science education and education per se. During the period discussed, science education was still in an incipient stage of development. As a result the rubric of general

\footnotetext{
* Ph.D. Research Scholar, Zakir Husain Centre for Educational Studies, School for Social Sciences, JNU, New Delhi-110067. Email: pjmshr108@gmail.com
} 
education provides a backdrop for situating the discussion on science education. Furthermore, as happened in the case of general education, the publication of books on science and science textbooks were linked up with publication houses and networks associated with the emergence of Hindi print culture. Without delving into a detailed history of print culture in Hindi, this paper discusses the linkages between science textbooks in Hindi and Hindi print culture.

\section{Situating the Popularization of Science}

Recent studies in the history of science engaging with the popularization of science have focused upon the audiences and reading publics of science, which it is argued, should be seen against the backdrop of the history of education as well (Secord 2004; Topham 2009; Shapiro 2012, pp.99-110). Shapiro's studies on precollegiate level science textbooks indicates that before the nineteenth century, textbooks served both the purposes, as a 'text-for-training' and 'books-for-popularization'(Shapiro, 2012, p. 99). Discussing the historiography of popular science Andreas W Daum emphasized on a more interdisciplinary approach and emphasizes that we 'de-essentialise' and 'historicise' popular science" (Duam, 2009, p.320). Furthermore, to understand "popular science" in its various forms, requires addressing the 'persistent sociological and discursive imbalances' in the already rich and extensive historical studies which will provide a more comparative picture of the field. Thus he suggests that the researcher begin with a set of 'heuristic categories' within local, regional and national contexts of 'transcultural communication' so as to understand 'forms of popular science as specific variations of a much larger phenomenon: that is transformations of public knowledge across time, space and cultures' (Duam, 2009, p.320).
In the same vein, James Secord argued against studying the history of popular science as a sub-discipline within history of science. In this view "popular science" cannot be used as a neutral descriptor because of its intrinsically multi-vocal character, and to overcome mid-nineteenth century diffusionism (Secord, 2004, p.671). Peter Broks instead suggests shifting to 'a whole range of participatory and indigenous forms, of practitioners, knowledge producers, knowledge consumers, commercial interests, political interests, political aspirations and social fears', thereby revealing the interrelationship of knowledge, culture and society (Broks, 2006,p.2). Similarly, Topham urges us to look at popularization as a communicative process which involves appreciation, resistance and cultural contestation (Topham, 2009, p.20). In the process popularization must be factored into the histories of the book and education:

\footnotetext{
"This has the benefit of reintegrating 'science popularisation' with other forms of communication in science, including education and international communication, and it also provides a range of new historiographical resources, drawn from, among other places, the cultural history of the book, translation studies and the history of education." (emphasis added, Topham 2009, p.20.)
}

Moreover, recent scholarship on the historiography on popular science emphasizes an interdisciplinary approach by integrating the studies of popular science with history of education and books as well. Thus, the focus here will be upon education, science education and what one might call the print readership in the Hindi speaking belt. During the colonial period the North-Western Provinces was known to be the heartland of the Hindi-Urdu region since the last decades of the eighteenth century. ${ }^{1}$ In 1836 , it was

\footnotetext{
1 Orisini points out that North West Province of the time included today's Uttar Pradesh, Uttrakhand, Rajasthan, Madhya Pradesh, Himachal Pradesh, and Haryana. Geographically, the Hindi area extended from the princely states of Rajputana (present Rajasthan) in the west, to Bihar in the east, and from Punjab and Garhwal in the north to the Central Provinces and Berar in the south (Orisini, 2002, p. 2).
} 
brought under the Lieutenant Governor after it was delineated from the Bengal Presidency, and Allahabad became the headquarters. In 1856, Oudh province was annexed and was governed by a Commissioner. In 1877, it was merged with the North-Western Province and together named North-Western Provinces and Oudh. In 1902, after some administrative changes it was renamed United Provinces of Agra and Oudh.

In the sections that follow we shall investigate the educational background and institutional endowments of the region, the emergence of Hindi as a language of communication and instruction, and its relationship with science book production in Hindi. The paper broadly attempt to explore nature and context of science education and science writings. The major concerns are-What kinds of informal and formal systems of education existed in the region? What was the scope/place of modern or traditional scientific knowledge in these educational systems? During the colonial period what was the language of instruction, and which subjects served were as pre-requisites for eligibility to entrance examinations for higher education? ${ }^{2}$ Entrance to institutions of higher education was through a qualifying entrance examination. In this context, what were the goals and objectives of science education and popularization? How widely were textbooks on science available in the vernacular languages? Who were the science writers and publishers of popular science textbooks and books at the time?

\section{The Ascent of Hindi as Language in NWP}

The introduction of the Charter Act of 1813 generated a major debate about the medium

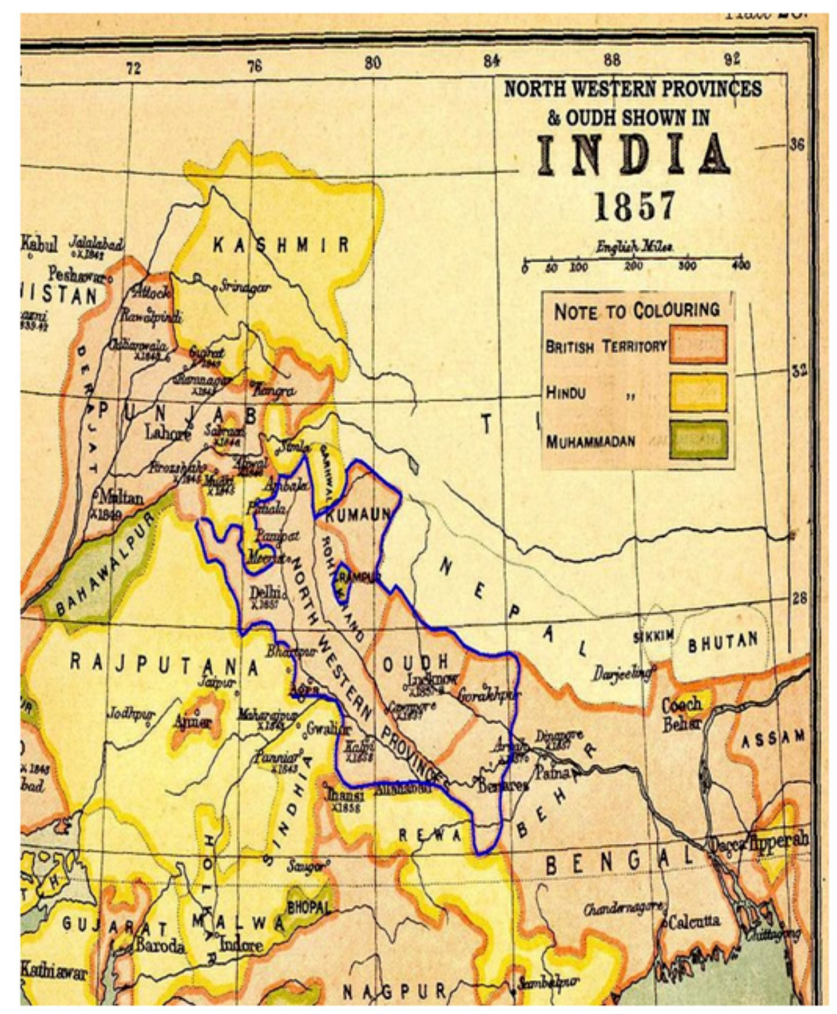

Fig.1. A Map of North-Western Province and Oudh ${ }^{3}$

of instruction between the Anglicists and Orientalists. The Anglicists, prevailed and their programme was legitimated by the Macaulay Minute of 1835, that recommended the extension of official patronage for instruction in English and western science and the withdrawal of financial support for education in Sanskrit, Arabic, or Persian (Baber, 1996, p. 202). The medium of instruction was a matter of great debate because English was alien to the local population. Capable English educated teachers were required in large numbers. The Wood Dispatch of 1854, on the contrary, made a case for the vernacular languages and private endeavors in education. In the nineteenth century regional languages like Marathi, Bengali, and Hindi were acquiring

\footnotetext{
2 The entrance examination was introduced for the Bachelors and masters degree at University level following the establishment of the university in 1857 onwards. See. Selections from the Educational Recordsof the Government of India 1859-71, 1960. pp.9-14.

${ }^{3}$ Map from personal copy of Imperial Gazetteer of India, vol. 25 (Atlas), (India 1857) published by Oxford University Press, 1908. Cropped, labeled, and scanned by Fowler\&fowler«Talk» 00:05, 2 June 2008 (UTC). From link- https://en.wikipedia.org/ wiki/North-Western_Provinces.
} 
literary prominence (Sneha, 2007, p.115). But in the case of Hindi the matter was complicated by the emergence of a politics centered around identitarian issues of language and religion. The debate on the medium of instruction in education emerged much later. The debate around Hindi was not restricted to the issue of Hindi as a medium of instruction but also the issue of distribution of administrative power, between two religious groups, i.e. Hindus and Muslims in NWP, wherein linguistic and religious identity came to be conflated (Rai, 1998, pp. 35-36). This caused the split of a common language i.e. Hindustani into two different languages Hindi and Urdu. Rai writes:

\begin{abstract}
"that there is but one common language of north India, which has at different times and by different people, been described as Hindi, Urdu and Hindustani. .. In the services of ulterior agendas, particular ends of this linguistic continuum have been sought to be hived off and infected with, on the one hand, Sanskritic, and on the other, Perso-Arabic borrowings. These latter processes have led to the emergence of two identifiable styles or registers, which I identify as "Hindi" and "Urdu” respectively"( Rai, 1998, p.15).
\end{abstract}

Historically it is not only a conflict between two languages, but it depicts also the fate of innumerable local paroles like Maithili, Braj, Kaithi etc. Orisini argues that, in the nineteenth century, Kharī Bolī Hindi rather than Braj Bhāṣā of Awadhi, in the Nāgarī script, instead of Kaithi or Mahajani, came to be regarded as 'standard Hindi' mainly through the agency of Fort William College and missionary textbook (Orisini, 2002, p.3). She opines that it was its institutional grounding that allowed the literary and historical discourse of Hindi-Hindu discourse to become hegemonic (Orisini, 2002, p.3).

Several missionary societies began to publish grammars, dictionaries and textbooks in Hindi which played a significant role in the standardization of Hindi. Though initially the missionary presses published Bengali text-books, they later began to publish a large number of Hindi textbooks ${ }^{4}$ as well which were used in Bihar, Benaras and North-Western Provinces prior to the establishment of Benaras and Agra School Book Societies (Pennar, 1970, cited in Dalmia, 1994. p. 172). In addition the American Presbyterian mission also printed a number of Hindi tracts and books ${ }^{5}$. Ulrike Stark notably exhibits how in the upper Gangetic region literacy gradually expanded after 1820 s with the establishment of missionary presses such as Surat Mission Press (1820), Sikundara Orphanage Press (1840), Allahabad Mission Press (1838), Mirzapur Orphan Press (1838), American Mission Press in Ludhiana (1836), Muzaffarnagar Mission Press (1846). Consequently, religious books and a growing market of textbooks made Hindi publishing a profitable business (Orisini, 2002, p.71).

The Hindi-Urdu controversy erupted during the 1860 s and 1870 s, through petitions, and memorandums submitted to the government demanding that Hindi in Nāgarī script be recognized as the official language. For the first time in 1868 an important official of the provincial government in charge of Public Instruction wrote a memorandum to the provincial government of NWP in this regard. In 1868, a memorandum by Rājā Shiv Prasad was presented to the government of North West Province to introduce the Nāgarī script as the Court Language. Rājā Shiv Prasad

\footnotetext{
${ }_{4}$ BhugolVritant(1825), PadarthVidyasar (1846) Rasayan Prakash Prasanottar(1847)published by the Calcutta School Book Society, Jyotish Chandrika by Omkar Bhatt published by the Agra School Book Society.

5 Evidently the publication of text-books in the vernacular was initiated by particular societies like the Agra Schools Book Society(1835), Calcutta School Book Society (1817, in 1823 Calcutta Tract and Book Society), Benaras Tract Society (1827), Delhi Society, Madras School Book Society(1820), The Bombay Book Society(1820) etc. These were the societies which began to publish the textbooks in vernacular languages like Bengali, Urdu, Hindi, Marathi, Tamil, etc (Dalmia, 1994, pp.169175).
} 
had served as inspector of schools. ${ }^{6} \mathrm{He}$ had been a member of the Legislative Council of the Viceroy and honored with the title of Rājā and C.I.E (Sitare-Hind) in 1874. The government received memorandums again in 1869, 1872 and 1873. In 1873 the petitioners presented a memorandum to the Lieutenant Governor, Sir William Muir asking for 'the restoration of Hindi or Nāgarī characters' in all courts and offices using the Persian script'( King, 1994, p.131). This precipitated a conflict between two religious groups and crystallized in the politics of group identity. The question of the script was transformed into a dispute over language between two religious groups.

Furthermore, various literary societies and associations played a vital role in creating a linguistic consciousness and in the assertion of linguistic identity. Vasudha Dalmia, Francesca Orisini and others have pointed out that various literary associations through the print media,kavi sammellans etc. were effective in making language a community issue where writing and reading became the point of cultural self-assertion in the late nineteenth century (King, 1994; Orisini, 2002; Dalmia, 1994).

\section{Education and Hindi Text-Books}

After Macaulay's Minute (1835) recommending official patronage for instruction in English and western science and Governor General, Lord Auckland's Minute (1839) giving outlines of an educational policy of far greater importance in northern India (Dodson, 2005, p.820) a large number of educational institutions in the region came under the control of the General Committee of Public Instruction and were regulated by its officials. In the light of the institutional transformation of education, there was a demand for the preparation and publication of science textbooks particularly in Hindi. Though the policy was directed towards the preparation of vernacular textbooks of useful knowledge in Hindi and Urdu but any endeavor in this regard could hardly meet the requirements. The Hindi publishing industry at the time was limited and the missionary presses focused upon the publication of works on grammar, language instruction or religious texts (Orisini, 2002; Stark, 2008.). In 1843, the jurisdiction of the General Committee of Public Instruction was transferred from the Supreme Government (of Bengal) to local bodies. ${ }^{7}$ The first report of the educational department of the North-Western Provinces recorded that English education did not extend into the upper provinces (Sen, 1991, p.169). S N Sen points out that this was due to the absence of incentives or stimulus for the study of English as there was neither a 'wealthy body of European merchants,' nor a supreme court where justice was administered in English in the region (Sen, 1991, p.169). The North-Western Provinces had two types of government schools at the primary level.

(i) The Upper level of vernacular education comprising the Tehseelee school system. This system was established in 1850 .

(ii) Below the level of the Tehseelee Schools, there were two types of village schools: the Indigenous schools and the Hulkabundee or circuit schools.

The Tehseeldari Schools were located in the town and were within the reach of students residing in the immediate neighborhood. These schools offered a more liberal education than was offered at the other schools. ${ }^{8}$ The Wood Dispatch of 1854, however, made a case for the vernacular languages and private endeavors in education. The medium of instruction in these schools was either Hindi or Urdu in many instances. According to

\footnotetext{
${ }_{6}$ Rājā Shiv Prasad joined NWP Education Department in 1856 as joint Inspector of schools, Benaras Circle. He was assisting British Inspector Ralph Griffith, a well known Sanskrit Scholar as well (Dodson and Hatcher, eds.2013, Vol. 74).

7 Selections from the Educational Records of the Government of India, Educational Reports, (1859-71), 1960.

8 Selections from the Educational Records of the Government of India.Educational Reports, ( 1859-71), 1960. p.52.
} 
the report of 1859-60 the course of study comprised:

“... Reading, Writing, Grammar, Composition, Arithmetic, Mensuration, Algebra up to Quardratics, the first four books of Euclid, the History and Geography of India, General Geography, Ancient History, the Elements of Political Economy, Plane table, Surveying." "

The village schools were of two kinds: Indigenous schools and the Hulkabundee schools. The indigenous schools were under government inspection but not under government management and were managed by private associations or by private teachers. On the other hand, the Hulkabundee or circuit schools were directly under government management. The villages were portioned into circuits, and a school was established at each one of the circuits. The Hulkabundee schools commenced class room teaching in 1843-44. The reports of 1858-59 suggest that the circuit schools, wherever introduced, had revolutionized popular education. Furthermore, "it has introduced useful and instructive studies, and an efficient organization in place of an utter absence of books without any system." 10

The Secretary of the Council of Education, FJ Mouat's report of 1853 on vernacular education points to a great difference between Tehseelee schools and Indigenous schools. In the Tehseelee schools the pupils had a fair elementary knowledge of arithmetic and geography (including mapping towns, rivers etc.). He writes:

\footnotetext{
"Some of them demonstrated with quickness and correctly, problems from the portions of Euclid read by them, and most of them read with ease simple prose compositions in Urdu and Hindi.’(Richey, 1922, p. 259)
}

On the other hand, describing Indigenous schools, he reported that because of poor infrastructure the school was busily employed in laborious physical exertion. Writing about the performance of the students he writes:

\begin{abstract}
'Arithmetic was the only branch in which they exhibited any degree of proficiency, and in this one or two small boys worked out puzzling additions and multiplications of odd and fractional numbers with wonderful quickness and facility, but it was evidently a mere laborious effort of memory without any attempt to expand the intellect or to educate the senses. Of geography, geometry or anything else they seemed to know nothing whatever.'(Richey 1922, p. 259)
\end{abstract}

The report suggests that the 'Higher Classes' professed to educate students up to the level where they were ready to enter a college or university (Richey, 1922,p. 42). During the early decades of the nineteenth century in Bengal, there were nine collegiate level schools with collegiate facilities, and 36 zillah schools which were divided into two grades: one with a course of 9 years study that provided instruction up to the university entrance level with English as medium of instruction; and the other schools providing a six year course with the vernacular as medium of instruction. According to the report of 1861-62 there was only one institution belonging to this Higher Class in the North-Western Provinces, this being Azmer School. Saugor School was another one transferred from the Central Provinces to North-Western Provinces (Richey, 1922, p.44). The reports for the year 1865-66 suggest that perhaps the facilities for higher and middle school education were the most meagre in the NorthWestern Provinces.

A report of $1859-60$ reveals that the designation of the colleges as 'colleges of general

\footnotetext{
${ }_{9}^{9}$ Selections from the Educational Records of the Government of India. Educational Reports, (1859-71), 1960. p.52.

${ }^{10}$ Selections from the Educational Records of the Government of India. Educational Reports, (1859-71), 1960. p.52.
} 
Table 1. Expenditure on Education (1859-1862)

\begin{tabular}{|c|c|c|c|c|c|c|c|}
\hline & & $\begin{array}{c}\text { Bengal } \\
1859-60\end{array}$ & $\begin{array}{c}\text { NWP } \\
1861-62\end{array}$ & $\begin{array}{l}\text { Punjab } \\
1861-62\end{array}$ & $\begin{array}{l}\text { Madras } \\
1859-60\end{array}$ & $\begin{array}{l}\text { Bombay } \\
1859-60\end{array}$ & Total \\
\hline \multirow[t]{3}{*}{ Number of Institutions } & General Education & 7 & 3 & .. & 1 & 2 & 13 \\
\hline & Special Education & 3 & 2 & 1 & 3 & 1 & 10 \\
\hline & Total & 10 & 5 & 1 & 4 & 3 & 23 \\
\hline \multirow[t]{3}{*}{ Average enrollment } & General Education & 556 & 908 & .. & 260 & 100 & 1,824 \\
\hline & Special Education & 386 & 176 & 67 & 207 & 52 & 888 \\
\hline & Total & 942 & 1,084 & 67 & 467 & 152 & 2,712 \\
\hline \multirow[t]{3}{*}{ Total expenditure(Rs.) } & General Education. & $1,60,777$ & $1,27,075$ & $\ldots$ & 53,742 & 64,350 & $4,05,944$ \\
\hline & Special education & $1,96,179$ & 69,663 & 37,495 & 68,631 & 29,777 & $4,01,745$ \\
\hline & Total & $3,56,956$ & $1,96,738$ & 37,495 & $1,22,373$ & 94,127 & $8,07,689$ \\
\hline
\end{tabular}

(Source: Selections from the Educational Records of the Government of India, Educational Reports, 1859-71, Volume 1. Manager of Publications Government of India, New Delhi)

education' was scarcely appropriate, they functioned more as schools, as far as their constitution, and courses of study were concerned. The first two of the colleges mentioned were affiliated to Calcutta University(Richey, 1922, p.30). The colleges at Agra and Banaras were originally purely Oriental seminaries, but were later transformed into Anglo-Vernacular Institutions, even though the study of Oriental classics was found to stand in the way of a more liberal education suited to modern needs (Richey, 1922, p. 259). The table below summarizes the number and kind of colleges, the respective enrolment and the expenditure on higher education in five regions that came under GCPI between 1859-1862.

Until 1861, there were 16 colleges in Bengal of which 9 were supported by the imperial government and 8 were of a private nature. These colleges in terms of the content of education imparted were of two kinds. There were colleges of general education and the others comprised those, where special education (professional education such as engineering and medical) was imparted (Richey, 1922, p. 6-30). In NWP (including the Central Provinces) there were 9 colleges of which 5 were Government Colleges and 4 were private institutions. Of the 5 government colleges in NWP, 3 provided a general education (Agra College founded in 1823, Banaras College founded in1792 and Bareilly in 1837) and 2 were for special education (Thomson Engineering College founded in 1847, and Agra Medical College founded in 1855 - both were later affiliated to Calcutta University). ${ }^{11}$

The Table 1 suggests that the expenditure was the lowest for the colleges of general education in the North-Western Provinces ${ }^{12}$. The same was true of special education, as well as medical education, and engineering.$^{13}$

Thus, the scale of overall higher education in NWP was not large enough to stimulate the development of a modern literary public. Moreover, colonial efforts at the time did little to revolutionize higher education during this period. On the other hand, primary education was also suffering from various shortcomings such as poor infrastructure, absence of books etc. Based on archival accounts such as records or educational

\footnotetext{
${ }^{11}$ See Selections from the Educational Records of the Government of India, Educational Reports, (1859-71)1960. p.9-30.

${ }^{12}$ Selections from the Educational Records of the Government of India, Educational Reports (1859-71) 1960, p.15.

${ }^{13}$ Selections from the Educational Records of the Government of India, Educational Reports (1859-71) 1960, p.16.
} 
reports it seems that after the 1890s the progress in the education system was more substantial, and was reflected in terms of the structural development of the education system, examinations, considerations towards selection, introduction, and regulations regarding books as well.

J S Cotton's review on the progress of education for the years 1892-93 to 1896-97 indicates that there were different kinds of examinations for secondary schools conducted by two different bodies - one being the University of Allahabad and other was the Department of Education NWP. The University of Allahabad conducted several examinations for Secondary schools - the Matriculation ${ }^{14}$ and the School Final as well as the Special Vernacular Examination. On the other hand, the Department conducted an English Middle Examination and the Vernacular Middle Examination (Cotton, 1898, p.156).

The School Final examination was introduced in 1894-95 and acquired popularity in comparison with the Matriculation, and was ranked alongside the latter as an entrance examination to the University. Cotton observed that the number of candidates for Matriculation was affected by the introduction of the School Final. The course for the School Final included science, drawing, commercial subjects, and an oral test in English (Cotton, 1898, p.156).

Secondary schools were those institutions occupying the middle ground between colleges and Middle schools. The upper grade was roughly fixed by the Matriculation standard of the universities; the lower grade was quite indefinite. They were further subdivided into: (a) High and (b) Middle schools, the former being those where instruction was up to the Matriculation. These institutions were further divided into those where English and the vernacular were the medium of instruction respectively. All high schools belonged to the former class, while the middle schools were equally divided between the two Anglo-Vernacular and Vernacular schools. Anglo-Vernacular and Vernacular schools followed the same rules, curriculum, and science textbooks. However, the mathematics curriculum in the two types of schools was different. Firstly, the syllabus for arithmetic in the Vernacular schools was more extensive than that of the Anglo-Vernacular schools. In the former the students were prescribed to study simple and compound interest, discount, etc. along with mensuration but not algebra, while in the Anglo-Vernacular schools students were supposed to study arithmetic and algebra but not mensuration. ${ }^{15}$

In the Progress Report of education 1898, JS Cotton also discussed the middle school examination, elaborating in particular upon the English and Vernacular Middle School examination. The English middle school examinations were modified in 1891-92 to suit the bifurcation of studies in secondary schools and would eventually prepare their candidates for the School Final. The introduction of drawing was a considerable success while the results in elementary science were below satisfactory levels. In the Vernacular Middle School Examination more than three-fourths of the candidates enrolled took the paper in Urdu while the remaining onefourth took the examination in Hindi. The other subjects at this level included geography, history and physics. In 1896-97, the total number of candidates was 3416, of which 1521 passed - the percentage of successful candidates was $44 \%$. The success rate was much lower in mathematics (Cotton, 1898, p.157). The reports submitted by the examiners had this to say:

\footnotetext{
" indicate a general use of keys, abstracts, and cram books, which are often learnt
}

\footnotetext{
${ }^{14}$ It was also known as entrance examination (Cotton, 1898, p.84).

${ }^{15}$ See (Rules for the Anglo-Vernacular Middle Examination to be held in March or April, 1888.
} 
by heart to the neglect of the text-books; even when the latter are used, they, too were frequently learnt off by heart instead of being intelligently studied. This amounts to a serious indictment of Vernacular education as pursued in these Provinces, and it will take long to eradicate the fault." (Cotton, 1898, p.157)

Based on this these educational records and reports the discussion has attempted to reveal aspects of the educations system, such as infrastructure, expenditure on education regulations, student participation in examinations through Hindi as a medium of instruction and the paucity of the suitable science books. The next section elaborates upon the socio-political contexts, which catalyzed Hindi books publication in general, and the distribution of Hindi science books in particular.

\section{The Education System in NWPO and THE Hindi Movement}

As discussed above after 1860s the Hindi - Urdu conflict acquired a renewed momentum through petitions and memorandums. Besides this, the language associations played a role in intensifying the awareness of linguistic identity. This section engages with how this socio-political milieu of linguistic identity was catalyzed the Hindi publishing industry and prompted some literary individuals or intellectuals to establish publishing houses. Ulrike Stark argues that this endeavor of intellectuals was both an entrepreneurial endeavor and intellectual vocation (Stark, 2008. p.1, pp. 72-83). Various archival sources reveal that some of these literary individuals had a direct or indirect association with the education department. In the latter decades of nineteenth century, these intellectuals had a close association with the education system which alerted then to the demand for educational books in Hindi. This triggered large-scale Hindi book production in general and increase in science book production in particular, after 1880s.
The role of associations, which were engaged in the reform and revival of religion or in the propagation of the language, was also significant in stimulating the growth of reading, writing and publishing in Hindi. Through the print media they also generated a kind of linguistic consciousness. Noteworthy were the Aligarh Bhasa Improvement Society (i.e. Hindi), Satya Dharma Volambin̄̄ Sabhā, Dev Nāgarī Pracārin̄̄ Sabhā, Hindu Samāj, and Ārya Samāj. Satya Dharma Society, founded in 1878 enlisted support not only from Aligarh but from other parts of the country. By 1882, the organization had published a few books, written by members in the Nāgarī Script. The general aim of the Aligarh Bhasa Improvement Society founded in 1881 , was to improve Hindi, regarded as the true vernacular of the country, through the publication of original works and the translation of other works from both ancient and modern world languages. Devnāgarī Pracārin̄i Sabha was founded by Gauri Datta who had participated in the Hindi- Nāgarī Movement in 1882. By 1889 the Sabha established a school, the Devnagari Pāthśālā in which children received a primary education in Hindi. The Hindu Samāj of Allahabad came into existence in 1880 under the leadership of Pandit Madan Mohan Malaviya. It soon took up the cause of Hindi. Ārya Samāj founded in 1875 by Dayanand Saraswati played an important role in the promotion of Hindi by publishing books in Hindi in Punjab and to a lesser role elsewhere in North India. Most significantly the Nāgarī Pracārinī Sabhā was founded in 1893 by Shiv Kumar Singh,Jagannath Das 'Ratnakar' and Radha Krishna Das. It was established for the promotion of the Nāgarī Script and Hindi Literature, a library of Hindi and English books and journals, initiating a search for old Hindi manuscripts, compiling a Hindi dictionary for scientific terms, and constructing a permanent headquarter building. Against this backdrop Benaras and Allahabad were emerging as the centers of Hindi Literature in the second half of the nineteenth century (King, 1994; Dalmia, 1994; Orisini, 2002). 
In 1882 , over 67000 signatures were collected by several NWP\&O organizations collected in favor of Hindi and Nāgarī and were sent to the Hunter Commission along with more than hundred memorials. ${ }^{16}$ Twenty eight witnesses from the province either appeared before the commission or sent their written testimony - the witnesses included Babu Shiv Prasad, Babu Harishchandra, and Sir Syed Ahmad Khan (King, 1994, pp.133-34). After 1880s voices for the elevation of Hindi as a national language could be heard. The need for asserting a linguistic and nationalist identity can be seen in the memorial of 1882:

\begin{abstract}
"The object of national education is to lift the nation to higher thoughts and ideas, and to insure it to a higher social, moral and political existence than at the times obtains therein. This can only be encompassed principally by means of a national language and national literature. In Bengal and Bombay much progress has already been made by way of founding a national literature."17
\end{abstract}

Dalmia argues that the memorialists were acutely aware of the effective influence of its incorporation in education or learning, in the creation of what they named 'national literature'. Thus, the endeavor towards the elevation of higher social, moral thought was a central element in this linguistic upsurge. Moreover, during these decades, the issue of textbooks became a matter of serious consideration in the education department as well, and was resulted in the formation of provincial text-book committees. Alfred Croft a professor of Presidency College and later the Director of Public Instruction, in his memorandum dated $24^{\text {th }}$ June 1890 refers to the resolution of $29^{\text {th }}$ March 1873 as the earliest remark on the issue of text books, by the Government of India, when appointing provincial committees for the examination of text-books. ${ }^{18}$ Quoting from the resolution:
"His Excellency in Council considers that more general revision of the books used in all the courses of public teaching is still expedient, and in some respects even necessary." "19
Further:
"...for this purpose it has been determined that all Local Governments and Administrations shall be requested to appoint committees to examine and report upon the class-books that are now prescribed in all those schools which receive any formal support from the State, in order to discover defects either in form or substance, and to adopt more carefully the course of authorized reading to the general educational policy." 20

A provincial committee was appointed and in its report, the committee recommended the creation of a standing committee in each province to choose or, if necessary, to prepare appropriate

\footnotetext{
${ }^{16}$ It was sent to the Hunter Commission which was appointed under the chairmanship of Sir William Hunter. The commission was appointed to review the progress of education in India. King opines that Hunter commission became the focus of extensive campaign in NWP\&O, particularly to bring a change in the language policy of provincial governments. ( King 1994. pp.13334)

${ }^{17}$ Extracts from the memorial by the residents of Allahabad as available in Court Character and Primary Education in the N.-W. Provinces and Oudh (Section iv, 90)compiled and edited by Madan Mohan Malviya (Allahabad, 1987). Cited in Dalmia, 1994, p.222.

${ }^{18}$ Alfred Croft had joined Presidency College as Professor of Philosophy. He had been Director of Public Instruction for the period 1877-1897. See. Derek, Waller, 1990, p. 193., Whitehead, 2003, p.23.

19 ....'Text-books for Public-aided Schools.' Proceedings of the Government of the N.-W. Provinces and Oudh, in the Educational Department, May 1891.

20 'Text-books for Public-aided Schools.'Proceedings of the Government of the N.-W. Provinces and Oudh, in the Educational Department, May 1891.
} 
text-books. ${ }^{21}$ By 1887, the content of text books became problematic and one of the first issues to come up was that of values and morals. In 1887 , the Secretary of State suggested that a text-book of morals be prepared. In 1889, it was decided that rather than have a separate text book on morals, values and morals should be incorporated into the already existing school textbooks. ${ }^{22}$ Subsequently in 1890 it was reported to the Government of India that another arrangement had been made by Nesfield, the then Inspectors of Schools. The Syndicate of the University appointed Nesfield and the Director of the Public Instruction for the Compilation of textbooks for the entrance examination as well to prepare a new set of readers in English and Vernacular of a good moral tone. Naturally on a sensitive issue such as this, a dispute erupted between Nesfield and Munshi Newal Kishore which led to the constitution of a Text book Committee. ${ }^{23}$ Gradually, a set of rules was issued regarding the preparation, sanction, prescription and authorization of the textbooks for schools. ${ }^{24}$ Subsequently in 1890, for each administrative circle rules for (a) the selection of vernacular books (b) the selection of English books, were issued by Government Director of Public Instruction. In 1893, the Director of Public Instruction pointed out that the Government rules of 1890 were ineffectual. ${ }^{25}$ Until 1893, in the North West Province, there were four Inspectors of circles with four committees under them for the selection of text-books for Anglo-Vernacular and Vernacular schools(Cotton, 1898, p.395). In that year, it was decided to appoint a single provincial committee, consisting of 40 members, of which 20 were ex officio. This committee met annually and was appointed to consider the recommendation of sub-committees assigned for the actual selection of books in different branches of studies. All recommendations were required to be sanctioned by the Director. ${ }^{26}$

In May 1894, a resolution was published, regarding the rules for the provincial Text-book Committee. ${ }^{27}$ These rules covered both the introduction of books and discontinuation of any book in use by the Government but the power of accepting and rejecting the proposals of the subcommittee was left with the Director of Public Instruction who had to inform the Government of his decision. ${ }^{28}$ Thus, a number of books were placed for recommendation before the subcommittees of books. ${ }^{29}$. Some of these were part of the prescribed syllabus for Government school and some of were not. The number of books placed before the committee suggests an ample range of publishing houses and availability of the books. The writing of textbooks had become an

\footnotetext{
${ }^{21}$ Text-books for Public-aided Schools.'Proceedings of the Government of the N.-W. Provinces and Oudh, in the Educational Department, May 1891.

${ }^{22}$ See Public Instructions in NWP and Oudh. File No. 83A. List No. 21 (C), pp.2-3.

${ }^{23}$ See Public Instructions in NWP and Oudh. File No. 83A. List No. 21 (C), UPSA, pp.2-3

${ }^{24}$ See Public Instructions in NWP and Oudh. File No. 83A. List No. 21 (C), UPSA, pp.2-3

${ }^{25}$ See Public Instructions in NWP and Oudh. File No. 83A. List No. 21 (C), UPSA, p4.

${ }^{26}$ See Public Instructions in NWP and Oudh. File No. 83A. List No. 21 (C), UPSA pp. 2-3.

${ }^{27}$ See Public Instructions in NWP and Oudh. File No. 83A. List No. 21 (C), UPSA p4.

${ }^{28}$ They could also recommend the changes in the text-books prescribed by the University or by Government or by the Director for Vernacular and Anglo-Vernacular schools, and may make suggestions for the preparation of any new books. See Public Instructions in NWP and Oudh. File No. 83A, List No. 21(C), UPSA. p.4. A number of books were placed before the sub-committees for recommendation.

${ }^{29}$ See Public Instructions in NWP and Oudh. File No. 83A, List N0. 21 (C) UPSA.p.4. Apart from this Alfred Croft also described in his memorandum that, in November 1889, he issued a circular for prescribing for the examination in 1892 and recommended a large number of alternative books. See also 'Text-books for Public-aided Schools.' Proceedings of the Government of the NW Provinces and Oudh, in the Educational Department, May 1891. File No. 372/1891. List No. 21 (C) UPSA p.7.
} 
occupation or source of earning for the writers by the $1880 \mathrm{~s} .^{30}$

\section{The Networks of Education and Publishing Houses}

Scholars like King and Orisini point out that after the formation of the U P Textbook Committee in 1894, unofficial pressure on the committee was exerted by publishers, literary associations, and their members in education departments for recommendation of books. Hindi intellectuals were becoming more involved and sensitive to education and related areas wherein the first generation of these Hindi scholars found employment as well (Orisini, 2002, p.96).

\begin{abstract}
"This osmosis between British and Indian officials and private writers and publishers was the beginning of a trend that was to become dominant when Textbook Committees transferred to private publishers and authors the task of preparing textbooks for the regular curriculum. Among the first publishers to jump at this opportunity were the Indian press of Allahabad, which gained an almost complete monopoly in UP, Macmillan Co. of Calcutta, and Khadgvilas Press in Bihar. "'31
\end{abstract}

Till the middle of the nineteenth century there were few Indian owned presses in NWP, mostly were in Benaras, Lucknow and Agra (Stark, 2008, pp.49-64). The presses published books, journals, pamphlets, and newspapers in Hindi, Sanskrit, Arabic, and Persian languages for both Hindu and Muslims. Both communities were writing extensively in Urdu. The canvas of publications included subjects such as education, science, law, medicine, poetry, guides to social behavior, yet the largest number of publications dealt with one or another aspect of religion(Stark, 2008, pp.49-64).

In the nineteenth century, publishing was not only an entrepreneurial activity but was an intellectual vocation as well. Ulrike Stark describes most of the publishing houses in India were established and run by the people who were not only businessmen but were deeply involved and committed to various literary and intellectual activities of that time and 'shared its larger cultural, cognitive, and social concerns'(Stark. 2008. pp.49-64). It was fairly evident in Hindi publishing as well. In the context of Hindi publishing, there were some printing presses, which were run by individuals who were government officials in the education department, educationists, teacher or professors, literary associates and members or founder of the institutions engaged in popularizing science in Hindi. ${ }^{32}$ Khadgavilas Press, Bhārat Jiwan Press,

\footnotetext{
${ }^{30}$ It was partly because of changes in the education department designed to meet the requirements of appropriate textbooks,that resulted in the establishment of textbook committees. In addition, the rise of the Hindi movement which commenced in played a significant role, since there were direct or indirect linkages between the education department and the intellectuals involved in the Hindi movement. As King also elaborates that the U.P. Textbook Committee was formed in 1894 and its duties included; selection of books for government, recommend changes in prescribed textbooks, make suggestions for the publication of new books, and to draw up lists of books for school prizes and school libraries. However, most of the work was done by the subcommittees of which Hindi sub-committee was a part. King highlighted that initially Hindi native speakers were not a part of the Hindi Sub-committee. A few Hindi literati managed to bridge this gap between the policy of committee and Hindi associations with their work in other branches of the department (King, 1974, cited in f.n.160 in Orisini 2002, p.96.).

${ }^{31}$ Apart from this, Archival sources also shows that publishing houses, Chandrprabha Press and Indian press, as it founders and associates were Hindi intellectuals and were officials in education department and literary associations as well. These were private publishing houses but books published from these press were prescribed in schools as well. See also Orisini. 2002. , p.96. See Proceedings of Provincial Text-book Committee. March 1908. See also 'Text-books for Public-Aided Schools.' Proceedings of the Government of the N-W Provinces and Oudh, in the Educational Department, May 1891.

${ }^{32}$ Such as Munshi Naval Kishore, Lakshmishankar Mishra, etc. See Rules for the Anglo-Vernacular Middle Examination to be held in March or April, 1888. See also A Letter "To the Secretary to Government, United Province.From T.C. Lewis, Esq.,M.A., Director of public instruction, United Province.”1903 . See also (Stark 2008.)
} 
Bhāratmitra Press, Chandraprabha Press, Indian Press, Munshi Naval Kishore Press, Nāgarī Pracārinī Sabhā, Vigyān Parishad were among these publishing houses. Ulrike Stark has studied the history of the book in India through the case study of MunshiNawal Kishore Press (NKP henceforth), Lucknow. Munshi Naval Kishore Press was established in 1858 by C.I.E. Munshi Naval Kishore who had been made Honorary Assistant Commissioner in 1881 and Fellow of University of Allahabad in 1887. According to Stark, NKP was driven by two objectives, that of revitalizing India's literary and cultural heritage on the one hand and to contribute to Indian modernization through the diffusion of knowledge and education on the other hand.

The Indian Press was established by Babu Chintamani Ghosh in 1884 . He was a pioneer editor and had contacts with the education department, and Nāgarī Pracārin̄̄ Sabhā (NPS) through litterateurs such as Mahavir Prassad Dwivedi, Shyamsundar Das (Orisini, 2002, p.72). The association of Shyamsundar Das proved to be a boon since they could produce educational books published by the Nāgarī Pracārinī Sabhā. In 1928 the Press entered an agreement with NPS to print all its publications and a branch was opened in Benaras (Orisini, 2002. p.72.) A number of science books were published in Hindi by Indian Press, many of which were prescribed in schools. ${ }^{33}$ Orisini writes that though:

\footnotetext{
"... the Indian Press was commercial in establishing high printing standards for Hindi publications. Chintamani Babu was particularly fond of character-building biographies (43 titles between 1909 and 1940), 'useful literature', religious books for both adults and children and quality illustrations" (Orisini 2002, p. 72)
}

Khadgavilas Press was a pioneering literary publishing house founded in 1880 at Bankipur, Patna. It had a monopoly over textbooks in Bihar until 1930. To begin with, it published Bhartendu Harishchandra's books, and translations of Bengali novels and Sanskrit plays such as Mudrarakasasa and Satya Harishchandra. Later on, a colonial official, the Director of Public instruction in Patna in 1877, Bhudev Mukhopadhyay's own Press namely Bodhodaya Press collaborated with it (Orisini, 2002. pp. 7172). Similarly, Chandraprabha Press was established in 1882 by an educationist Lakshmishankar Mishra. Lakshmishankar Mishra had been professor of Benaras College, later served as district school inspector. He was associated with Nāgrī Pracārinī Sabhā of Benaras and contributed as a promoter of Hindi as well ${ }^{34}$. The demand from the educational sphere was also met by a few British Indian officials who were publishers, educationists, and teachers as well. These too played a role in catalyzing the Hindi book publishing in the 1880s.

There were other endeavors of science writings in Hindi. For instance, many Hindi science dictionaries were prepared by different scientific and literary societies. Nāgarī Pracārin̄̄ Sabha was an institution established primarily for the promotion of Hindi and Nāgarī but it contributed for the promotion of science as well. The Sabha from the early years of its establishment recognized and decided to publish a glossary for science in Hindi. The idea first came up in 1894 but could not be taken up because a glossary of new terms had still to be conceptualised due to the lack of words in Hindi which connoted scientific terms. The NPS decided to constitute a sub-committee in 1898. Due to the difficulties in translation and coining scientific terms in Hindi it appealed to few scientific writers to be allowed

\footnotetext{
${ }^{33}$ See Rules for the Anglo-Vernacular Middle Examination to be held in March or April, 1888. See also School Courses and Textbooks in Primary and Secondary Schools, See also 'Text-books for Public-aided Schools.' Proceedings of the Government of the N.-W. Provinces and Oudh, in the Educational Department, May 1891.

${ }^{34}$ See Puraskaraur Padak se Sambandhit Niyamavali Pustak, 1941. See also Upadhyay,1994.
} 
to coin scientific terms in Hindi. ${ }^{35}$ As mentioned in the report:

\begin{abstract}
"It was further urged that if the few scientific writers of Hindi should be allowed to coin words as they liked, not knowing, or caring to know, what writers before them had done, a time might come when scientific study in Hindi would prove to be an impossibility owing to the existence of several Hindi words for a single technical word in English. ${ }^{936}$
\end{abstract}

The first edition of dictionary was published in 1902. After 1929 a different dictionary for physics, chemistry and mathematics were published (Lal and Tripathi, eds. 1954, p.35.) Towards the end of the $19^{\text {th }}$ century, and the beginning of the 20th century Gurukul Kangdi, an institution established by a branch of the Arya Samaj, introduced Hindi as a medium of instruction. In coordination with the Nagari Pracharini Sabha, it also prepared a scientific dictionary and some text books (Pataria, 2000, p.32; Sharma, ed, 1962)

Similar developments followed in Allahabad, another emerging centre of Hindi Literature. Professors Ganganath Jha, Hammiduddin, Ramdas Gour, and Shaligram Bhargava who taught Sanskrit, Arabic, Physics and Chemistry respectively at Muir Central College, formed an association, the Vigyan Parishad, in 1913 towards further dissemination of scientific knowledge in Hindi (Prakash, 1999. p. 63). It began to publish a Hindi science journal namely Vigyan. In 1930-31 Vigyan Parishad prepared a science encyclopedia containing 4821 words (Pataria 2000, pp. 34-35.). In 1939 an encyclopedia entitled Hindi Vishwa Bharati was introduced under the editorship of Shri Krishna Ballabh Pant and is considered the reference book in Hindi (Pataria, 2000, pp. 31-34).

\section{Science Books and Textbook Production in Hindi}

Science writing comprises a vast arena including science textbooks, general science books, popular science books, science journalism, magazines, etc. In any particular society or culture, this kind of readership and authorship as well, is linked to a great extent with the education system, socio-political context and institutional set up of a region. An appreciation of the context of the production, distribution, circulation, and consumption of books provides a clearer picture of the science writing or popularization of science in any textual culture. An earlier section discussed the socio-political milieu and institutional backdrop for the production of books in Hindi, the next section explores the pathways and institutions involved in the production and distribution of Hindi books in general. ${ }^{37}$

An account from a government report for 1861-62 reveals that the distribution of the books in NWP was solely dependent on government agencies such as the Government Curator and Book Depot at Head Quarters and they were sold in the interior regions through the agencies of officers of the department on a commission basis. ${ }^{38}$

\footnotetext{
"These sales are more directly in the hand of the Deputy Inspectors, who indent on the Allahabad Depot for such books as may be required in their respective districts. A large discount is allowed by Government for cash purchase, and a commission on sales to a certain amount is granted to the Deputy Inspector, it being the object of government to effect quick and ready sales at the lowest possible price."(See Selections from the Educational Records of the Government of India, Educational Reports, 1960. p.52, 77-78).
}

\footnotetext{
${ }^{35}$ Varshik Vivaran, 1893-1902, 1902-03. Nagari Pracharini Sabha. pp. 6-10.

${ }^{36}$ Varshik Vivaran, 1893-1902, 1902-03. Nagari Pracharini Sabha. pp. 6-10.

${ }^{37}$ Not in terms of economic analysis but in terms of structural analysis of the system.

${ }^{38}$ See Selections from the Educational Records of the Government of India, Educational Reports, (1859-71). 1960. p.52,pp.77-78
} 
Reports from Bengal for 1863-64 indicate that in Bengal it was not government but the School Book and Vernacular Literature Society, which was instrumental in the preparation and distribution of textbooks. These societies were like an Educational Institution setup by a Committee of gentlemen associated with the task of providing and disseminating a supply of suitable School books and School Apparatus together with large number of Vernacular publications for general reading throughout the country ' ... as a means of advancing the education of people.'

The publication of science textbooks in Hindi commenced after 1840s but these were very few in number. One or two books on astronomy were published in the second decade of the $19^{\text {th }}$ century - these were translations of English books on the subject. One of the books was Bhugol Vritanta (1825) published by the Calcutta School Book Society and the other was Jyotish Candrik $\bar{a}$ by Omkar Bhatt published by the Agra School Book Society. Evidently the publication of textbooks in the vernacular was initiated by particular societies like the Agra School Book Society, Calcutta School Book Society, Delhi Society, Madras School Book Society, The Bombay Native Education Society, Benaras Institute etc ${ }^{39}$. These were the societies, which began to publish the textbooks in vernacular languages like Bengali, Urdu, Marathi, Tamil, Hindi, etc.

In this context, Dodson's paper provides significant insights regarding the introduction of vernaculars science textbooks during early nineteenth century in the northern part of the Indian sub-continent, particularly in Hindi. He describes the context behind the translation and construction of vernacular text-books:

"The liberal concern to impart Western learning and science to affect India's civilizational progress continued to dominate the content of educational curricula, while earlier orientalist expertise in, and appreciation for, Indian languages and cultural forms were adapted for the purpose of more readily facilitating the introduction and acceptance of this body of knowledge among India's learned elites"(Dodson, 2005, p. 820).

He suggests that there were a variety of Indian language textbooks written during the 1830 s, but it was realized by European educators that those were 'unsufficiently tailored to suit 'native' taste and sensibility' (Dodson, 2005, p.820, f.n.45). Consequently, under the Governorship of Lord Auckland a sub-committee of the Government's General Committee of Public Instruction was formed for constructing a comprehensive corpus of textbooks "under one general scheme of superintendence" (Dodson, 2005, p.820 f.n.45). By 1843, the responsibility of preparing vernacular textbooks in Hindi and Urdu was to be transferred to North-Western Provinces Government at Agra with the transfer of educational responsibility from Calcutta to Agra in 1843 (Dodson, 2005, p.820; f.n. 45).Orisini points out that the availability of textbooks for primary and middle schools was dependent upon missionary efforts or the efforts of company officials such as William Kempson, Shiv Prasad Singh in Benaras, A W Fallon, George A Grierson, and Bhudev Mukhopadhyay in Bihar (Orisini, 2002, p.96). These figures supported Hindi that was labeled as the 'language of people'. Until the middle of the nineteenth century the publications covered subjects such as education, science, law, medicine, poetry, guides to social behavior, yet the largest number of publications dealt with one or another aspect of religion. This also explains why Shiv Prasad Singh and Bhudev

\footnotetext{
${ }^{39}$ Calcutta school Book society was founded on 1817. Agra School Book Society was founded on 1837. Bombay Native Society was founded in 1820s. Madras School Book society was established in earlier in 1820 and revived in 1867 and renamed as "Madras School Books and Vernacular Literature Society". Delhi Society was founded in 1830s. Benaras Institute was established in 1864 (Mishra, 2001; Bhatia, 1987, p.22 ; Venkkateshwaran, 2002).
} 
Mukhopadhyay set out to write translate, and commission text-books in Hindi.

The Agra School Society and the Aligarh Scientific Institute played a significant role in the publication of Hindi text books. Serampore (a Baptist mission) in Bengal first began to publish science books in Hindi, English and Bengali. This organization was involved in the study of language and translation activity from the beginning, both independently and in association with Fort William College. Mission stations were established quite early in the North, and the printing press eventually appeared in North Indian cities such as Ludhiana (1836), Allahabad (1838), and Agra (1840) (Bhatia, 1987, pp. 100-1). After the resignation of Gilchrist from Fort William College, the college's reign over Hindi Grammar and text book production came to an end. Till that point it voluntarily (missionary, educational and literary) was in the forefront of support for Hindi. This departure called for changes within the tradition and signaled new developments in government patronage and language politics. (Bhatia, 1987, pp.100-1)

The first book published in Hindi on chemistry was the Rasāyan Prakāś Praśnottari and was published in 1847 by Agra School Society. The Calcutta School Book Society also introduced some science text books like Padārth Vidyāsār (1846). In 1856 Sulabh Rasāyan Sanksipt by J.R. Valentine, Rasāyan Sangraha by Vishwambhar Nath Verma, in 1898 Rasāyan Prakāś by Badrilal were published(Bhatia 1987.p.25). The books on mathematics began appearing after the books on chemistry. The first book on mathematics published in Hindi was the Büjganitā in $1850^{40}$ written by Bapudev Paranjpe. Lakshmishankar Mishra, Sudhakar Dwivedi, Brajmohan Lal,
Navinchandra Rai, Munshi Ratanlal were prominent writers who produced mathematics text books. Bapudev Paranjpe wrote B̈̈jganita in 1850, Munshi Ratanlal wrote Mensuration in 1880, and Middle School Mensuration in 1910, Navinchandra Rai wrote Jal-Sthiti aur Jal-Gati and Sthiti-tatva aur Gati-tatve in 1882 (Mishra. 2001. pp.25-70.).Similarily Sudhakar Dwivedi and Lakshmishankar Mishra wrote books on mathematics. Both were teachers in Benaras Sanskrit College. Books written by Sudhakar Dwivedi on mathematics were Calan-Kalan (1885), Cala-Rāśi Kalan (1885), Pañca Siddhāntikā (1889). Sudhakar Dwivedi composed a compilation of scientific terminology in Hindi entitled Hindi Vaigyānik Koșa (1905). Furthermore, five books on physics were published before 1900, these being DautBijli Bal (1871/78) by Sohan Lal, Padārth Darśan (1873) by Mahendranath Bhattacharya from Calcutta, Padārth Vigyān Vitap (1875) by Lakshmishankar Mishra and Vinayak Rao and Ragad Bijli (1881) by Mohanlal (Mishra 2001.pp.25-70). The first book on zoology in Hindi was the Prānīsāstra, again a translation by Vinayak Rao, published in 1882. However, textbooks exclusively targeted for students were written only after 1928.(Mishra 2001. pp.25-70.) The first book on botany was the Vitap Vilās published in 1897 and it was the only book on botany published in Hindi in the $19^{\text {th }}$ century.

Major Indian-owned publishing houses such as Khadgavilas Press, Chandraprabha Press, Indian Press, Munshi Nawal Kishore Press, Bharatjeewan Press, etc., manifest the double commitment discussed above. ${ }^{41}$ The owners or associates of these publication houses were either government officials, teachers or had close

\footnotetext{
${ }^{40}$ Apart from this there was another book "B̈̈jganita" which was published in 1949 from Caukhamba is a translation of Bhaskaracharya and it was translated by Achyutananda Jha. It is a Hindi reading of Bhaskaracharya "Bïjganita." Ibid.

${ }^{41}$ Archival sources also reveals it. See Rules for the Anglo-Vernacular Middle Examination to be held in March or April, 1888. See also School Courses and Text-books in Primary and Secondary Schools; 'Text-books for Public-aided Schools.' Proceedings of the Government of the N.-W. Provinces and Oudh, in the Educational Department, May 1891. p.7. See also Orisini 2002. p.96 ;
} 
linkages with officials in the education department. Most of the presses were established during late 1870 s or 1880 s, when the Hindi movement was acquiring a new momentum. Educationists and British officials like Thakur Chandi Singh ${ }^{42}$, Munshi Newal Kishore, Babu Chintamani Ghosh, Pandit Lakshmishankar Mishra, Munshi Zakaullah Khan were among the initiators of different printing presses for publishing Hindi books. Most of the Hindi science books introduced in schools were published from the presses with which these intellectuals were associated. Arithmetic in four parts for different classes by the Education Department was published by Munshi Naval Kishore Press, Ganita Kaumud̄̄ aur Risālausul-i-Hișāb in Hindi and Urdu written by Pandit Lakshmishankar Mishra, published from Chandraprabha Press, Mental Arithmetic in three parts written by Thakur Chandi Singh, Mensuration written by Munshi Ram Ratan Lal and published from Munshi Naval Kishore Press, had been the prescribed textbooks in vernacular schools in NWP since 1891. Various parts of these books were written and prescribed for various classes from class three to middle school.

Most of the Hindi science books prescribed in schools were published by Indian Press, Government Press, Munshi Naval Kishore Press, Chandrprabha Press etc. These presses published numerous Hindi books, including Hindi science books. Educational records show that many of these were prescribed andrecommended for the vernacular primary schools and middle schools by the Department of Public Instructions. ${ }^{43}$

\section{Hindi Science Journalism}

The origin of Hindi science journalism can be traced to the second decade of the $19^{\text {th }}$ century.
The Serampore Mission (a Baptist mission) Press was established in the 1800 in Bengal. It began to publish books in Hindi, English and Bengali. Under the editorship of Clark Marshman it published a monthly journal Digdarśan in English and Bengali. Later a Hindi translation was also published. The Press also printed "the second report of the Institution for the support and encouragement of Native Schools" where it is suggested that the first three books in Hindi were published in the Nāgarī script (Pataria, 2000, p.27). The first issue of Digdarśan carried two articles on science that entitled: 'America Ki Khoj' and 'Gubbaredwārā Ākāsh Mein Yātrā.' The second issue carried more articles: 'England Mein $\mathrm{Na}$ Ugne Wale Vraksha' and 'Bhāp Kā Engine.' Some issues of this journal were introduced in schools by the Calcutta School Book Society (Pataria, 2000, p.27). Similarly, some readers such as "Ajamgarh Reader" were published from the Allahabad Mission Press (Mishra, 2001, p.3).

The Agra School Book Society was established in 1837 and began to publish a weekly - Buddhi Prakāśa from 1852, which also contained articles related to science, following which the Aligarh Scientific Institute was established in 1862 in Aligarh in the North-Western Provinces. It started a weekly called the Aligarh Institute Gazette from 1866, which contained articles on different subjects like agricultural method, agricultural instruments, techniques etc. S. Irfan Habib points out that these scientific institutions did not merely impart scientific education but emphasize the need for a socio-cultural change in contemporary Indian society. Discussing the Aligarh Scientific Society he classified the activities of the society into four activities: translation of western science into local languages, practical attempts to popularize machanised

\footnotetext{
${ }^{42}$ Mental Arithmatic, written by Thakur Chandi Singh - offg. Head Assistant, office of Inspector of Schools, Oudh Lucknow. Book prescribed by Educational Textbook committee NWP and Oudh, 1891.

${ }^{43}$ List of the Textbooks Sanctioned For Use in the Vernacular Schools of the North- Western Provinces and Oudh, 1895. Allahabad Regional Archives.
} 
farming, delivering lectures on the topics of common interest and highlighting the sociopolitical problems of the country. The society translated around 40 European books dealing with history, political science, geography, meteorology, electricity, algebra, geometry, calculus, hydrology and agriculture. Habib further elaborates the process through which Sir Syed Ahmed Khan popularized science and technology and devised it as an instrument in socio-cultural change. According to him agriculture as an art had become quite extinct among the Indian cultivators, and apart from mere translation and literary activity it was essential to demonstrate with modern mechanics the processes of the cultivation of land. He wrote a pamphlet Qadim Nizam-i-Dehhi-iHindustān on Indian agriculture. The society also procured a "V" pump and an American pump and demonstrated its experiments. Vegetables, dals and cotton were cultivated from European and American seeds respectively and popularised (Habib, 1985, pp. 299-312).

In 1882, Lakshmishankar Mishra, a professor from the Benaras College started a journal Kāsí Patrikā published from Calcutta. The front page of the journal carried the master heading "A Weekly Educational Journal of Science, Literature and News in Hindustani" that was printed below the name of the journal.

Until the end of $19^{\text {th }}$ century contributions largely came from the Kāśi Nāgrī Pracārinī Sabhā established in 1893 in Kashi. This played a significant role as the forum for Hindi science literature. In 1900, it began to publish Saraswati, a monthly journal on literature and science and carrying articles on science with illustrations. A list of Hindi newspapers and journals some of which carried articles on science are given in table 2 (Mishra, 2001).

There were two types of journals which carried articles on science in Hindi:

- Literary journals: which carried articles on literature, polity, science etc. Except for Vigyan
Table 2

\begin{tabular}{|c|c|}
\hline Journals/Magazines & First Published \\
\hline Kavivachan Sudhā & 1867 \\
\hline Hariścandra Magazene & 1877 \\
\hline Hindi Pradeep & 1881 \\
\hline Anand Kādambin̄̄ & 1881 \\
\hline Nāgrī Pracārin̄̄ Patrikā & 1896 \\
\hline Saraswati & 1900 \\
\hline Maryāāā & 1910 \\
\hline Sammelan Patrikā & 1913 \\
\hline Vigyān & 1915 \\
\hline Mādhurī & 1922 \\
\hline Suddhā & 1927 \\
\hline Veenā & 1927 \\
\hline Viśāl Bhārat & 1928 \\
\hline Gang $\bar{a}$ & 1930 \\
\hline Hindustān̄̄ & 1931 \\
\hline
\end{tabular}

published by Vigyān Parișad all the journals mentioned in the table above come under this category.

- Scientific journals: Vigyān was the only journal which belonged to this category and that also began to publish after 1915 .

Scientific societies such as the Benaras Institute (1864), endeavored to popularize science in Hindi through the translation of textbooks of philosophy, mathematics, astronomy, and geology. The Nāgarī Pracārinī Sabhā of Benaras, was an organization formed in 1893 to advance Hindi's claim as a self-sufficient modern language, and sponsored translations of textbooks and the compilation of a scientific dictionary in Hindi. Sutphen and Andrews point out that through institutions such as Nāgarī Pracārin̄̄ Sabhā and the Hindi Sāhitya Sammelan (1910) in Allahabad, Hindi intellectuals were engaged in constructing a literary canon, through books, promoting a sudh (pure) version of the Hindi language, and publishing suitable Hindi books, including books on medicine and science.(Andrews and Sutphen 2002 p.21.) The magazine Saraswati had played a little significant role in science journalism in Hindi. It was founded in 1900 in Allahabad under 
the editorship of Mahavir Prasad Dwivedi and its contents included articles on science and history as well as literature. The table mentions very few journals or magazines that carried science articles in Hindi before 1900 and those were again literary

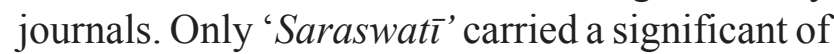
science articles in comparison to other literary magazines. However, this too commenced after 1900.

\section{Conclusion}

The study has attempted to trace the beginnings of science writing in Hindi - both as a popular genre, as well as its deep connection with the preparation of textbooks. This has required identifying the linkages with the education system and the place of science education within the system. The growth of a Hindi readership was closely linked with education in Hindi and thus the growth of the science readership in Hindi was tied up with the development of the education system. Both were greatly dependent upon the production of textbooks and popular books in Hindi.

To get a sense of the science readership in Hindi it was essential to examine science education in Hindi particularly at the pre-collegiate level. This provided an understanding of the sociopolitical context of Hindi as a language and its literature - revealing the social background, and education of science writers. Secondly, it provided an overview of the process of science communication in Hindi during the period extending from 1860 s to $1900 \mathrm{CE}$. The educational records and reports reveal that not only was the field of science education underdeveloped till the 1890s when compared with the other vernaculars, but there was a paucity of science text books.

The production of science books in Hindi could not be studied in isolation from Hindi book production. Both primary and secondary sources suggest that it was only after 1860s Hindi book production began to take off. Until 1850s most of the published vernacular textbooks of "useful" knowledge published in NWP were written in Urdu (Dodson, 2005, pp. 820). Orisini argues that in comparison, Hindi was slow to find its way into print: until the 1860s Hindi publishing was confined to primers and textbooks produced by missionaries and for the Education Department (Orisini, 2004, p.113). The number of Hindi textbooks available for educators in the NWP, however, tended to be much smaller than Urdu, and sometime also were indeed dated (Dodson, 2005, p.822). Most of the books in Hindi were published by missionaries or to some extent through the efforts of colonial officials or Indians employed by the colonial state such as Raja Shivprasad or Bhudev Mukhopadhyay.

Hindi book production expanded after 1860s in NWP and three factors were responsible for this expansion: the growth in the number of printing presses, changing educational policies and finally the politics of linguistic identity affected science education and readerships in Hindi as well. The study examined a number of institutions that took up the cause of Hindi as a language and promoted its implementation as a language of instruction as well as examined the relationship between these institutions. Moreover, it dwells on the socio-political and institutional context of the development of a Hindi readership and thus a science readership in Hindi along the axes of education and science popularization.

Several archival sources and scholarly works exhibit that production of science book in Hindi became visible after 1870 s and 1880 s, when both the Hindi movement and print culture had consolidated themselves. Similarly, science journalism also developed after 1890s, particularly following the publication of the magazine Saraswati that commenced publication in 1900. Before this, very few science articles were published by Kāśi Patrikā, and from the Calcutta School Book Society and occasionally by some literary magazines. The establishment of journals 
and magazines carrying science articles in Hindi, and the number of publications of these articles indicates that in the nineteenth century science writings through journalism was confined to the literary societies, though few scientific societies were already in existence .

\section{BiBLIOGRAPHY}

\section{Primary Sources}

A Letter "To the Secretary to Government, United Province. From T.C. Lewis, Esq.,M.A., Director of public instruction, United Province." File No. 344, November, 1903, Department of Public Instruction NWP and Oudh. 1888. List no. 14., Education Department, Proceeding Nos.1-21.Uttar Pradesh State Archives, Lucknow.

Cotton, J.S. Progress, Education in India, 1892-93 to 189697. Third Quinquennial Review. Her Majesty's Stationary Office. 1898.

Proceedings of Provincial Text-book Committee. File No. 42/1909. Proceeding Nos. 57, March 1908. List No. 10. Uttar Pradesh State Archives. Lucknow.

Proceedings of the Government of the N.-W. Provinces and Oudh, in the Educational Department, May 1891. File No. 372/1891. List No. 21 (C) . Uttar Pradesh State Archives, Lucknow.

Public Instructions in NWP and Oudh. File No. 83A. List No. 21 (C ). Uttar Pradesh State Archives, Lucknow.

Puraskaraur Padak se Sambandhit Niyamavali Pustak, 1941.NagriPracharini Sabha. NPS Library. Benaras.

Richey., J.A. Selections from Educational Records, Part II, 1840-59. Superintendent Government Printing, Calcutta, 1922.

Rules for the Anglo-Vernacular Middle Examination to be held in March or April, 1888.

Department of Public Instruction in NWP and Oudh File No. 67/89, List No. 57. Education Block, 1888. Uttar Pradesh State Archives. Lucknow.

School Courses and Text-books in Primary and Secondary Schools. File No. 385A/1. List No. 21(C ). Uttar Pradesh State Archives, Lucknow.

Selections from the Educational Records of the Government of India 1859-71, Volume 1. Manager of Publications Government of India, Delhi. 1960.
'Text-books for Public-aided Schools.' Proceedings of the Government of the N.-W. Provinces and Oudh, in the Educational Department, May 1891. File No. 372/ 1891. List No. 21 (C) Nos. 1-4. Uttar Pradesh State Archives, Lucknow.

\section{Secondary Sources}

Broks, Peter. Understanding Popular Science, Open University Press. Glasgow, 2006.

Chandra, Bipin; Mridula, Mukherjee; Aditya, Mukherjee; K N Panikkar; Sucheta Mahajan. India's Struggle for Independence. Penguin Books, India. 1989.

Dalmia, Vasudha. Nationalization of Hindu Tradition: Bhartendu Harishchandra and Nineteenth Century Benaras, Oxford University Press, Delhi, 1994.

Desai, A. R. Social Background of Indian Nationalism. Popular Prakashan, Mumbai, 2000.

Dodson, Michael S. Translating Science, Translating Empire : Power of Language in Colonial North India. Comparative Studies in Society and History, Vol 47.4, 2005.

Dodson, Michael Sand B A Hatcher, eds. Trans-Colonial Modernities in South Asia, Vol. 74, Routledge, 2013

Duam, Andreas W. Varieties of Popular Science and the Transformations of Public Knowledge: Some Historical Reflections, Isis, Vol. 100.2(2009):320.

Habib, S Irfan. Institutional efforts: Popularisation of Science in the mid $19^{\text {th }}$ Century, Fundamenta Scientiae, Vol. 6.4 (1985):299-312.

King, Christopher. R. One Language Two Scripts: The Hindi Movement in The Nineteenth century North India, Oxford University Press, New Delhi, 1994.

King, R Christopher.'Nagari Pracharini Sabha of Benaras, 1893-1914: A Study of the Social and Political History of the Hindi Language' unpublished Ph.D. Theses, University of Wisconsin,1974, pp.297] cited in Orisini, Francesca The Hindi Public Sphere 1920-1940: Language and Literature in the Age of Nationalism, Oxford University Press, 2002.

Lal, Shrikrishna;Tripathi, Karunapati (eds) Heerak Jayanti Granth. Nagari Pracharini Sabha. Benaras, 1954.

List of the Textbooks Sanctioned For Use in the Vernacular Schools of the North- Western Provinces and Oudh, 1895, Allahabad Regional Archives.

Map from personal copy of Imperial Gazetteer of India, vol. 25 (Atlas), (India 1857) published by Oxford 
University Press, 1908. Cropped, labeled, and scanned by Fowler\&fowler«Talk» 00:05, 2 June 2008 (UTC). From link- https://en.wikipedia.org/wiki/NorthWestern_Provinces.

Mishra, Shivgaopal. Swatrantata-Poorva Hindi Mein Vigyan Lekhan Ke Sau Varsh, Vaigyanik and Takniki Shabdawali Ayog, Ministry of Human Resource, Government of India, New Delhi, 2001.

Mishra, Shivgopal. Hindi Mein Vigyan Lekhanke Sau Varsha. vol. 1 and 2, Vigyan Prashar, New Delhi, 2001.

Orisini, Francesca. The Hindi Public Sphere 1920-1940 : Language and Literature in the Age of Nationalism, Oxford University Press, New Delhi, 2002.

Orisini, Francesca. Pandits, Printers, and Others; Publishing in Nineteenth Century Benaras in Abhijit Gupta and Swapan Chakravorty (ed.) Print Areas: Book History in India, Permanent Black, Delhi, 2004.

Pataria, Manoj Hindi Vigyan Patrakarita,Takshila Prakashan, New Delhi, 2000.

Pennar, Peter. The James Thomson School in Northern India,1822-53: A Biographical and Administrative Study.Ph. D. Diss. McMaster University, 1970, Cited in Dalmia, Vasudha. Nationalization of Hindu Tradition: Bhartendu Harishchandra and Nineteenth Century Benaras. Oxford University Press, 1994.

Prakash, Gyan. Another Reason: Science and the Imagination in Modern India. Princeton University Press, Princeton, New Jersey, 1999.

Rai, Alok. Hindi Nationalism: Tracts for the Theme, Orient Longman, New Delhi, 1998.

Raina, Dhruv; Habib. S. Irfan. Domesticating Modern Science: A social History of Science and Culture in Colonial India.Tulika Books, New Delhi, 2004.

Sarkar,Sumt. Modern India.1885-1947, Macmillan, Delhi, 1983.

Secord, James. Knowledge in Transit, Isis. vol. 5.4(2004)

Sehgal, Narendra K; Sangwan, Satpal; MahantiSubodh. "Unchartered Terrain: Essays on Science Popularisation in Pre-Independence India”, Vigyan Prasar, New Delhi, 2000.

Selections from the Educational Records of the Government of India, Educational Reports, 1859-71, Volume 1, Manager of Publications Government of India, Delhi.1960.

Sen, S N. Scientific and Technical Education in India : 1781-1900, Indian National Science Academy, 1991.
Shapiro, Adam R. "Between Training and Popularisation : Regulating Science Textbooks in Secondary Education”, Isis, vol.103.1(2012):99-110.

Sharma, O P. (eds) Trends in Scientific Terminology. National Bureau of Educational Publications, 1962.

Sneha.The politics of Language and Identity in Higher Education: Pandit Madan Mohan Malaviya and The Establishment of Benaras Hindu University, Unpublished Ph. D. Theses. submitted to Jawaharlal Nehru University, New Delhi. 2007.

Stark, Ulrike. Empire of Books : The Nawal Kishore Press and Diffusion of the printed word in Colonial India, Permanent Black, New Delhi. 2008.

Sutphen, P Mary and Andrews, Bridie. Medicine and Colonial Identity, Routledge Publication, London, 2002.

Tej, K. Bhatia. A History of Hindi Grammatical Tradition: Hindi, Hindustani, Grammer, History and Problem, E.J. Leiden, Netherlands, New York. 1987.

Topham, Jonathan R. "Rethinking the History of Science Popularisation/Popular science." in Papanelopolou, Faidra, Nieto-Galan Agusti, Perdiguero, Enrique (eds.), Popularizing Science and Technology in the European Periphery, 1800-2000, Ashgate, 2009.

Ulrike, Stark. Empire of Books: The Nawal Kishore Press and Diffusion of the printed word in Colonial India, Permanent Black, New Delhi, 2008.

Upadhyay, Baldev. Kashi ki Panditya Parampara: Kashisth Sanskrit Vidvanoke Jeevancharit Avam Sahityik Avadanonka Pramanikvivaran, Vishwavidyalaya Parakashan, Varansi, 1994

Varshik Vivaran, 1893-1902, 1902-03, Nagari Pracharini Sabha, Benaras.

Venkkateshwaran, T V. The Topgraphy of A Changing World: Geology Knowledge during the late Nineteenth Century Colonial Madras Presidency, IJHS 37.1(2002).

Waller, Derek. The Pundits: British Explorations of Tibet and Central Asia, University Press of Kentucky, 1990.

Whitehead, Clive. Colonial Encounters: The British Indian and Colonial Education Service 1858-1883, J.B. Tauris, 2003.

Zaheer, Baber. Science of Empire; Scientific Knowledge, Civilization, and Colonial Rule in India, State University of New York Press, 1996. 